\title{
PENGARUH HARGA JUAL KACA PATRI JENIS SILVER TERHADAP NILAI PENJUALAN PADA CV. KARUNIA KACA PALEMBANG TAHUN 2004-2015
}

\author{
Oleh: \\ Hamid Halin \\ Fakultas Ekonomi UIGM Palembang \\ Email: hamidhalin@uigm.ac.id \\ Hendry Wijaya \\ Fakultas Ekonomi STIE Rahmaniyah, Sekayu \\ Email : hendrywijaya2001@gmail.com \\ Rinda Yusilpi \\ Fakultas Ekonomi STIE Rahmaniyah, Sekayu \\ Email : rindayusilvi88@gmail.com
}

\begin{abstract}
ABSTRAK
Studi ini melihat bagaimana harga jual efek kaca patri perak terhadap volume penjualan pada CV. Karunia Kaca Palembang. Selain itu, tujuan dari penelitian ini adalah untuk mengetahui harga jual efek kaca patri perak terhadap volume penjualan pada CV. Karunia Kaca Palembang. Dimana variabel X adalah harga jual dan variabel $\mathrm{Y}$ adalah volume penjualan. Jenis penelitian yang digunakan adalah kualitatif dan kuantitatif, dan sumber data bersifat sekunder. Teknik pengumpulan data melalui wawancara, dan dokumentasi. Teknik analisis yang digunakan dari hasil uji regresi sederhana yaitu bahwa variabel harga jual memiliki nilai negatif sebesar 2.734 yang berarti jika terjadi penurunan harga sebesar $1 \%$ maka akan meningkatkan volume penjualan sebesar $2.734 \%$. Dari hasil uji koefisien determinasi bahwa $\mathrm{R}$ square sebesar 0,908 menunjukkan variabel independen (harga jual) 90,8\% yang dapat menjelaskan variabel terikat (volume penjualan). Sedangkan sisanya 9,2\% terkena atau dijelaskan oleh variabel lain yang tidak termasuk dalam penelitian ini. Hasil uji t diperoleh sebesar 9,951 dengan tingkat signifikansi 0,000. Kemudian nilai ttest dibandingkan dengan ttabel pada $\mathrm{df}=12-2=10$ dan tingkat signifikansi 0,05 pada nilai ttabel 2,228 . Nilai nilai ttest Variabel X lebih besar dari ttabel $(9,951>2,228)$. Tingkat signifikan adalah $0,000<0,05$. Maka bisa dikatakan Ho ditolak dan Ha diterima. Jadi ini menunjukkan bahwa ada pengaruh yang signifikan terhadap nilai penjualan.
\end{abstract}

Kata kunci: Harga jual, volume penjualan

\section{PENDAHULUAN}

\section{Latar Belakang}

Pembangunan ekonomi di Indonesia merupakan salah satu bagian penting dari pembangunan nasional dengan tujuan akhir untuk meningkatkan kesejahteraan masyarakat. Perkembangan zaman dan teknologi menuntut kehidupan perusahaan untuk menentukan strategi yang akan ditetapkan perusahaan untuk mencapai tujuan. Untuk itu diperlukan perencanaan yang matang dalam mencapai tujuan tersebut. Semakin mudah suatu lingkungan berubah, maka dampak terhadap pelaksanaan strategi semakin besar. Begitu pula hal tersebut sangat penting dalam menentukan pengaruh harga.

Perusahaan dapat mempertahankan serta dapat meningkatkan tingkat keuntungan atau laba operasional perusahaan. Serta harga mempunyai pengaruh langsung bagi laba perusahaan. Harga merupakan komponenyang berpengaruh langsung terhadap laba perusahaan. Tingkat harga yang ditetapkan 
mempengaruhi kuantitas yang terjual. Selain itu secara tidak langsung harga juga mempengaruhi biaya, karena kuantitas yang terjual berpengaruh pada biaya yang ditimbulkan dalam kaitannya dengan efisiensi produksi. Oleh karena penetapan harga mempengaruhi pendapatan total dan biaya total, maka keputusan dan strategi penetapan harga memegang peranan penting dalam setiap perusahaan (Patra, 2015).

Menurut Abdurrahman (2015) Harga juga mempunyai peran utama dalam menciptakan nilai pelanggan dan membangun hubungan dengan pelanggan. Harga merupakan elemen ketiga dari bauran pemasaran dan satu-satunya elemen dalam bauran pemasaran yang menghasilkan pendapatan, sedangkan elemen lainnya melambangkan biaya. Secara sederhana, harga adalah sejumlah uang yang berfungsi sebagai alat untuk memperoleh produk atau jasa.

Menurut Swastha (2014) Nilai penjualan merupakan jumlah total yang dihasilkan dari kegiatan penjualan barang. Semakin besar jumlah penjualan yang dihasilkan perusahaan, Semakin besar kemungkinan laba yang dihasilkan perusahaan dalam kegiatan penjualan.

CV. Karunia Kaca Palembang adalah salah satu usaha bisnis yang bergerak pada bidang seni kaca. CV. Karunia Kaca Palembang berdiri pada tahun 2004 sampai dengan sekarang. CV. Karunia Kaca berada di wilayah Palembang tepatnya di Jalan Achmad Yani Tangga Takad, Plaju Palembang. CV. Karunia Kaca melayani pembuatan kaca patri yang diinginkan konsumen. Dengan menggunakan gambar dan desain yang dibuat melalui komputer sehingga gambar lebih akurat dan sama persis dengan ukuran yang akan dibuat.

Penjualan kaca patri dari tahun 20042015 berjumlah sebanyak kaca patri timah seluruhnya berjumlah $451 \mathrm{~m}^{2}$, kaca patri kuningan seluruhnya berjumlah $550 \mathrm{~m}^{2}$, dan kaca patri silver seluruhnya berjumlah $658 \mathrm{~m}^{2}$ kaca patri gold $620 \mathrm{~m}^{2}$, Berdasarkan jumlah tersebut, penelitian ini mengambil kesimpulan untuk meneliti kaca patri silver untuk penelitian Karena, dilihat dari jumlahnya kaca patri jenis silver berjumlah lebih banyak.

\section{Perumusan Masalah}

Berdasarkan latar belakang diatas, maka rumusan masalahnya adalah Bagaimana pengaruh harga jual kaca patri jenis silver terhadap nilai penjualan pada CV. Karunia Kaca Palembang?

\section{Tujuan Penelitian}

Adapun tujuan dari penelitian ini adalah untuk mengetahui bagaimana pengaruh harga jual kaca patri jenis silver terhadap nilai penjualan pada CV. Karunia Kaca Palembang tahun 2004-2015.

\section{Tinjauan Pustaka}

\section{Pengertian Bauran Pemasaran}

Menurut Sunyoto (2015) Marketing mix atau bauran pemasaran adalah kombinasi dari variabel atau kegiatan yang merupakan inti dari sistem pemasaran yaitu produk (product), harga (price), promosi (promotion), dan distribusi (place). Dengan kata lain marketing mix adalah kumpulan dari variabel yang digunakan oleh perusahaan untuk dapat mempengaruhi tanggapan konsumen.

\section{Pengertian Harga}

Menurut Ginting (2011) Harga merupakan salah satu unsur bauran pemasaran yang sangat strategis terhadap peningkatan volume penjualan, khususnya untuk menghadapi persaingan antar perusahaan yang memproduksi produk sejenis. Tentunya dalam menentukan harga jual perusahaan perlu melihat dari besarnya biaya produksi dan biaya non produksi yang telah dikeluarkan perusahaan, jangan sampai perusahaan menderita kerugian. Harga juga sering kali digunakan sebagai indikator nilai bilamana harga tersebut. Dihubungkan dengan manfaat yang dirasakan atas suatu barang atau jasa. Dengan demikian dapat disimpulkan bahwa pada tingkat harga tertentu, bila manfaat yang dirasakan 
konsumen meningkat maka nilainya akan meningkat.

\section{Pengertian Penjualan}

Menurut Abdurrahman (2015) Penjualan adalah suatu presentasi pribadi dengan melakukan hubungan dengan pelanggan dan melakukan tahap pembelian untuk memenuhi kebutuhan para konsumen. Penjualan adalah manipulasi yang membuat orang membeli sesuatu yang tidak dibutuhkan. Penjualan sama dengan istilah pemasaran yang merupakan kegiatan dalam pemasaran. Dengan adanya penjualan dapat tercipta suatu proses pertukaran barang/jasa antara penjual dan pembeli.

Menurut Sunyoto (2015) Harga sebagai sejumlah uang yang diminta untuk suatu produk atau suatu jasa secara lebih luas dapat dikatakan bahwa harga ialah jumlah semua nilai yang diberikan oleh konsumen untuk memperoleh keuntungan (benefit).Atas kepemilikkan atau penggunaan suatu produk atau jasa. Secara historis, harga menjadi faktor utama yang mempengaruhi pilihan seorang pembeli. Namun pada dekade ini faktor-faktor nonharga dinilai penting. Meskipun demikian, harga masih merupakan salah satu elemen terpenting yang menentukkan pangsa pasar dan tingkat keuntungan perusahaan.

\section{Pengertian Nilai Penjualan}

Nilai penjualan esensinya diterapkan dalam tiga apresiasi yaitu : pertama tingkat penjualan yang ingin dicapai, kedua pasar yang ingin dikembangkan sebagai kegiatan transaksi atau tempat melakukan transaksi dan ketiga adalah keuntungan atas penjualan. Ketiga esensi tersebut pada dasarnya memberikan batasan bahwa nilai penjualan diartikan sebagai penambahan nilai ekonomi yang ditimbulkan melalui aktivitas penawaran produk dari berbagai perusahaan industri yang menawarkan pembelian kepada konsumen (Abdurrahman, 2015).
Menurut Sunyoto (2015) Nilai penjualan yang berorientasi pada pertambahan omzet adalah keuntungan yang diperoleh atau dicapai sesuai dengan banyaknya produk yang ditawarkan dan dibutuhkan oleh konsumen, banyaknya jumlah transaksi yang terjadi dan banyak penawaran yang dilakukan sehingga menghasilkan keuntungan. Tentu peningkatan penjualan akan terjadi apabila jasa yang ditawarkan jasa tertsebut didistribusikan oleh piha-pihak yang melakukan transaksi penjualan produk.

\section{Metodologi Penelitian Lokasi dan Waktu}

Lokasi dalam penelitian ini berada di daerah Tangga Takad, Jalan Jenderal Achmad Yani No. 735/14, 16 Ulu, Seberang Ulu II, Kota Palembang, Sumatera Selatan 30252. Waktu penelitian ini berlangsung pada tanggal 28 November 2016 sampai dengan tanggal 12 Desember 2016.

\section{Batasan Penelitian}

Dalam penelitian ini penulis membatasi hanya meneliti pada Pengaruh Harga jual kaca patri jenis silver terhadap nilai Penjualan pada CV. Karunia Kaca Palembang.

\section{Jenis dan Sumber Data}

Dalam penelitian ini menggunakan jenis Pool Data, dimana data yang digunakan adalah data yang memiliki beberapa variasi/macam dalam rentang kurun waktu tertentu. Data yang digunakan dalam penelitian ini adalah data harga produk dan volume penjualan produk kaca patri jenis silver pada CV. Karunia Kaca Palembang dari tahun 2005 hingga tahun 2015.

Menurut Sunyoto (2015) Sedangkan sumber data yang digunakan dalam penelitian ini adalah data sekunder. Data sekunder adalah merupakan data publikasi yang dikumpulkan tidak hanya untuk keperluan satu riset tertentu saja. Data sekunder mencakup informasi yang telah dikumpulkan dan hanya mungkin relevan dengan 
permasalahan yang ada. Sumber data yang digunakan dalam penelitian ini adalah data sekunder berupa data harga produk dan volume penjualan produk kaca patri jenis silver, profil perusahaan CV. Karunia Kaca Palembang serta data studi empiris dan studi literatur yang terkait dengan penelitian ini.

\section{Teknik Pengumpulan Data}

\section{Wawancara}

Teknik pengumpulan data dengan wawancara dengan cara mengajukan pertanyaan kepada responden dengan pedoman wawancara, mendengarkan atas jawaban, mengamati perilaku dan mendengar respon dari survei. Wawancara digunakan sebagai teknik pengumpulan data apabila peneliti ingin melakukan studi pendahuluan untuk menemukan permasalahan yang harus diteliti (Sugiyono, 2015).

\section{Dokumentasi}

Teknik pengumpulan data dengan dokumentasi adalah suatu cara yang dlakukan untuk menyediakan dokumen - dokumen dengan bukti yang akurat dari pencatatan sumber-sumber informasi khusus. Bertujuan untuk memperoleh data yang langsung diambil dari tempat penelitian pada CV. Karunia Kaca Palembang. dokumentasi yang diambil dari tempat penelitian berupa data harga jual dan nilai penjualan dari tahun 2004-2015 serta data studi empiris dan studi literatur yang terkait dengan penelitian ini.

\section{Definisi Opersional dan Pengukuran Variabel}

Menurut Sugiyono (2014) definisi operasional adalah aspek penelitian yang memberikan informasi kepada kita tentang bagaimana caranya mengukur variabel. Definisi operasional merupakan informasi ilmiah yang sangat membantu peneliti lain yang ingin melakukan penelitian dengan menggunakan variabel yang sama. Karena berdasarkan informasi itu, kita akan mengetahui bagaimana caranya melakukan pengukuran terhadap variabel yang dibangun berdasarkan konsep yang sama. Dengan demikian kita dapat menentukan apakah tetap menggunakan prosedur pengukuran yang sama atau diperlukan pengukuran yang baru.

Variabel yang digunakan dalam penelitian ini adalah Harga Produk (Variabel $\mathrm{X}$ ) dan volume penjualan (Variabel Y) produk kaca patri jenis silver pada CV. Karunia Kaca Palembang. Harga Produk diukur berdasarkan harga produk tersebut dengan satuan rupiah, sedangkan Volume Penjualan Produk diukur berdasarkan jumlah produk yang terjual dengan satu meter persegi $\left(\mathrm{M}^{2}\right)$.

\section{Teknik Analisis}

Teknik analisis data merupakan proses yang mengatur urutan data, mengorganisasikanya ke dalam suatu pola, kategori, dan satuan uraian dasar. Teknik analisis data merupakan salah satu proses penelitian yang dilakukan setelah semua data yang diperlukan guna memecahkan permasalahan yang diteliti sudah diperoleh secara lengkap.

\section{Uji Analisis Regresi Linear Sederhana}

Uji analisis regresi adalah studi mengenai ketergantungan salah satu dependen (terikat) dengan salah satu atau lebih variabel independent (penjelas/bebas). Uji analisis regresi bertujuan untuk mengetahui apakah regresi yang dihasilkan adalah baik untuk mengestimasikan nilai variabel dependen. Untuk menjamin ketelitian dan keakuratan hasil perhitungan analisis regresi, maka digunakan alat bantu program SPSI versi 21. Peneliti menggunakan regresei linier sederhana yaitu hanya menggunakan 2 variabel dan bentuk hubungan antara variabel $\mathrm{X}$ dan variabel $\mathrm{Y}$ atau satu variabel independen dengan satu variabel dependen (Sugiyono, 2014).

Persamaan umum regresi linear sederhana adalah :

$Y=\alpha+\beta_{1} X i$ 
Jika menggunakan data yang tersaji dalam penelitian ini yaitu Pool Data dengan menggunakan data harga produk (Variabel X) dan Volume Penjualan (Variabel Y), maka model tersebut terlihat tidak linear dalam parameter, tetapi secara intrinsik bisa dibuat linear dengan transformasi model tersebut kedalam model logistik (logistic model) sebagai berikut:

$\ln Y i=\ln \beta_{0}+\beta_{1} \ln X i+u i$

$\ln =$ logaritma natural (logaritma dengan bilangan dasar $\mathrm{e}=2,71828$ )

Jika $\boldsymbol{Y i}^{*}=\ln \boldsymbol{Y} \boldsymbol{i}, \boldsymbol{\alpha}=\boldsymbol{\operatorname { l n } \boldsymbol { \beta } _ { 0 }}$, dan $\boldsymbol{X} \boldsymbol{i}^{*}=\ln \boldsymbol{X} \boldsymbol{i}$, persamaan tersebut dapat ditulis kembali menjadi:

$Y i^{*}=\alpha+\beta_{1} X i *+u i$

Model ini dinamakan dengan double-log model. Hal yang perlu diperhatikan dalam double-log model adalah, koefisien $\beta_{1}$ dapat ditafsirkan sebagai elastisitas yaitu persentase perubahan variabel $\mathrm{Y}$ sebagai akibat persentase perubahan variabel $\mathrm{X}$.

\section{Analisis Koefisien Determinasi}

Menurut Sugiyono (2014) Analisis koefisien determinasi $\left(\mathrm{R}^{2}\right)$ digunakan untuk mengetahui seberapa besar persentase sambungan variabel independen secara bersamaan terhadap terhadap variabel dependen. Nilai R square dikatakan baik jika diatas 0,5 karena nilai $\mathrm{R}$ square berkisar antara 0 sampai 1. Koefisien korelasi mempunyai kriteria-kriteria diantaranya sebagai berikut.

Tabel 1. Interprestasi Koefisien

\begin{tabular}{|c|c|}
\hline Interval Koefisien & Tingkat Hubungan \\
\hline $0,00-0,199$ & Sangat Rendah \\
\hline $0,20-0,399$ & Rendah \\
\hline $0,40-0,599$ & Sedang \\
\hline $0,60-0,799$ & Kuat \\
\hline $0,80-1,000$ & Sangat Kuat \\
\hline
\end{tabular}

Sumber: Sugiyono,(2014).
Uji t

Menurut Sugiyono (2015) Uji t atau uji parsial adalah pengujian yang masing-masing variabel independen terhadap variabel dependen guna mengetahui seberapa besar pengaruh masing-masing variabel independen terhadap variabel dependen dengan ketentuan.

$\mathrm{Ha}=$ Diduga Harga berpengaruh signifikan terhadap Volume Penjualan Kaca Patri jenis Silver pada CV. Karunia Kaca Palembang.

Ho = Diduga Harga tidak berpengaruh signifikan terhadap Volume Penjualan Kaca Patri jenis Silver pada CV. Karunia Kaca Palembang.

\section{Hasil Penelitian dan Pembahasan Hasil Penelitian}

Dalam bab ini peneliti menjelaskan hasil penelitian yang telah dilakukan oleh peneliti. Serta menyajikan data harga jual dan volume penjualan produk kaca patri jenis silver dari tahun 2004-2015 yang telah didapatkan peneliti dari CV. Karunia Kaca Palembang yang tersaji pada tabel berikut ini.

Tabel 2. Harga Jual dan Nilai Penjualan Kaca Patri Jenis Silver Serta Logaritma Natural

\begin{tabular}{|c|c|c|c|c|}
\hline Tahun & $\begin{array}{c}\text { Harga Jual } \\
\text { Kaca Patri } \\
\text { Silver } \\
\text { (Variabel X) }\end{array}$ & $\begin{array}{c}\text { Kaca Patri } \\
\text { Silver } \\
\text { Terjual Per } \\
\text { Meter } \\
\text { Persegi } \\
\text { (Variabel Y) }\end{array}$ & $\begin{array}{c}\text { Logalitma } \\
\text { Natural } \\
\text { Variabel X } \\
\text { (Ln X) }\end{array}$ & $\begin{array}{c}\text { Logalitma } \\
\text { Natural } \\
\text { Variabel Y } \\
\text { (Ln Y) }\end{array}$ \\
\hline 2004 & 1.450 .000 & 85 & 14.19 & 4.44 \\
\hline 2005 & 1.450 .000 & 78 & 14.19 & 4.36 \\
\hline 2006 & 1.590 .000 & 72 & 14.28 & 4.28 \\
\hline 2007 & 1.590 .000 & 68 & 14.28 & 4.22 \\
\hline 2008 & 1.590 .000 & 63 & 14.28 & 4.14 \\
\hline 2009 & 1.750 .000 & 58 & 14.38 & 4.06 \\
\hline 2010 & 1.750 .000 & 51 & 14.38 & 3.93 \\
\hline 2011 & 1.850 .000 & 47 & 14.43 & 3.85 \\
\hline 2012 & 1.850 .000 & 40 & 14.43 & 3.69 \\
\hline 2013 & 1.900 .000 & 37 & 14.46 & 3.61 \\
\hline 2014 & 1.900 .000 & 31 & 14.46 & 3.43 \\
\hline 2015 & 2.250 .000 & 28 & 14.63 & 3.33 \\
\hline
\end{tabular}

Sumber:CV.Karunia Kaca Palembang, 2016.

Berdasarkan data diatas dapat dilihat pada tahun 2005 hingga tahun 2015 terjadi perubahan harga yang berdampak langsung terhadap volume penjualan atas produk yang ditawarkan oleh perusahaan. Dari data diatas juga menggambarkan pengaruh antar variabel (Variable Slope) bersifat negatif, hal ini 
mengindikasikan bahwa setiap terjadi kenaikan harga produk yang ditawarkan oleh perusahaan akan langsung kepada jumlah produk yang terjual (volume penjualan produk).

Berdasarkan hasil penjelasan diatas, peneliti mengelolah SPSS versi 21 dengan menggunakan data harga jual dan nilai penjualan kaca patri silver pada CV. Karunia Kaca Palembang dari tahun 2004-2015 menggunakan uji regresi, uji koefisien determinasi dan uji t.

\section{Uji Analisis Regresi Linear Sederhana}

Uji Analisis Regresi Linear Sederhana adalah studi mengenai ketergantungan salah satu variabel dependen (terikat) dengan dengan salah satu variabel independent (penjelas/bebas). Besarnya perubahan pada faktor dependen (Y) akibat perubahan pada faktor independen (X) secara parsial dapat dijelaskan melalui persamaan regresi seperti yang tertera dalam tabel dibawah ini.

Tabel 3. Uji Analisis Regresi Linear Logistik

\begin{tabular}{|c|c|c|c|c|c|}
\hline \multicolumn{6}{|c|}{ Coefficients $\mathrm{s}^{\mathrm{a}}$} \\
\hline \multirow[b]{2}{*}{ Model } & \multicolumn{2}{|c|}{$\begin{array}{l}\text { Unstandardized } \\
\text { Coeff icients }\end{array}$} & \multirow{2}{*}{$\begin{array}{l}\text { Standardized } \\
\text { Coeff icients }\end{array}$} & \multirow[b]{2}{*}{$t$} & \multirow[b]{2}{*}{ Sig. } \\
\hline & B & Std. Error & & & \\
\hline (Constant) & 43.216 & 3.947 & & 10.950 & .000 \\
\hline Ln_X & -2.734 & .275 & -.953 & -9.951 & .000 \\
\hline
\end{tabular}

Sumber : Hasil Pengolahan SPSS v21

Berdasarkan pada tabel 3. uji regresi linear sederhana hasil output SPSS diatas maka persamaan regresi yang terbentuk adalah sebagai berikut:

$$
\begin{aligned}
& Y i^{*}=\alpha+\beta_{1} X i^{*}+u i \\
& Y i^{*}=43,216-2,734 X i^{*}
\end{aligned}
$$

Persamaan diatas dapat menunjukkan bahwa variabel harga jual memiliki nilai negatif 2,734 yang diartikan bahwa apabila terjadi penurunan harga sebesar $1 \%$ maka akan terjadi kenaikan nilai penjualan sebesar $2,734 \%$.

\section{Koefisien Determinasi}

Koefisien determinasi digunakan untuk mengukur seberapa besar presentase perubahan atau variasi dari variabel dependen bisa dijelaskan oleh perubahan atau variasi dari variabel independen. Hasil pengujian koefisien determinasi dapat dilihat dari nilai $R$ square Koefisien determinasi digunakan untuk mengetahui prosentase pengaruh variabel independen $(\mathrm{X})$ terhadap variabel dependen (Y). Maka nilai determinasi ditentukan dengan $\mathrm{R}^{2}$ (R Square). Dari hasil perhitungan didapatkan nilai koefisien determinasi sebagai berikut :

\section{Tabel 4. Koefisien Determinasi}

\begin{tabular}{l}
\begin{tabular}{|l|r|r|r|r|}
\multicolumn{1}{|c|}{ Model Summary } \\
\hline Model & $\mathrm{R}$ & $\mathrm{R}$ Square & $\begin{array}{c}\text { Adjusted } \\
\text { R Square }\end{array}$ & $\begin{array}{r}\text { Std. Error of } \\
\text { the Estimate }\end{array}$ \\
\hline 1 & $.953^{\mathrm{a}}$ & .908 & .899 & .11644 \\
\hline
\end{tabular} \\
\hline
\end{tabular}

Sumber : Hasil Pengolahan SPSS v21

Berdasarkan tabel 4. koefisien determinasi hasil output SPSS diperoleh angka, $\mathrm{R}$ square sebesar 0,908 hal ini menunjukkan bahwa 90,8\% varibel independen (harga jual) yang dapat menjelaskan variabel dependen (nilai penjualan). Sedangkan sisanya sebesar 9,2\% dipengaruhi atau dijelaskan oleh variabel lain yang tidak dimasukkan dalam penelitian ini.

\section{Uji T}

Uji t atau uji parsial adalah yang masingmasing variabel independen terhadap variabel dependen guna mengetahui seberapa besar pengaruh masing-masing variabel independen terhadap variabel dependen dengan ketentuan (Sugiyono, 2014).

\section{Tabel 5. Uji T}

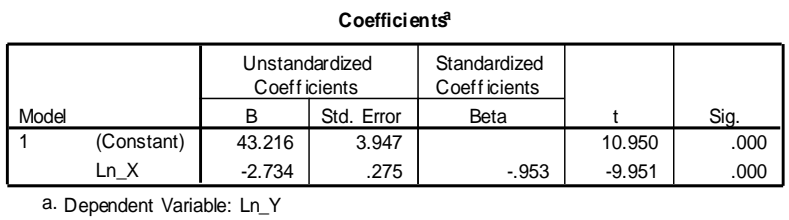

Sumber : Hasil Pengolahan SPSS v21 
Berdasarkan pada tabel 5. hasil output SPSS diatas maka diperoleh variabel harga 9,951 dengan taraf signifikansi 0,000. Kemudian $t_{\text {hitung }}$ dibandingkan dengan $t_{\text {tabel }}$ pada $\mathrm{df}=12-2=10$ dan tingkat signifikan 0,05 diperoleh nilai $t_{\text {tabel }} 2,228$. Nilai $t_{\text {hitung }}$ Variabel X lebih besar dari $t_{\text {tabel }}(9,951>$ 2,228). Adapun tingkat signifikan $0,000<$ 0,05. Pada Coefficiens Table diatas, nilai $t_{\text {hitung }}$ berslope negatif. Pada uji t, simbol negatif hanyalah menyatakan slope $\beta_{1}$. Jika nilai koefisien $\beta_{1}$ berslope negatif, maka nilai $\mathrm{t}$ hitung pun akan bernilai negatif. Sehingga angka yang digunakan dalam uji t hanyalah angka t hitung, tanpa menyertakan slope atas nilai t hitung tersebut. Dari hasil pembahasan diatas, maka dapat dnyatakan bahwa Ho ditolak dan $\mathrm{Ha}$ diterima. Sehingga menunjukkan bahwa ada pengaruh signifikan terhadap nilai penjualan.
1. $\mathrm{Ha}=$ Diduga Harga berpengaruh signifikan terhadap Volume Penjualan Kaca Patri jenis Silver pada CV. Karunia Kaca Palembang.
2. Ho = Diduga Harga tidak berpengaruh signifikan terhadap Volume Penjualan Kaca Patri jenis Silver pada CV. Karunia Kaca Palembang.

\section{Kesimpulan}

Berdasarkan hasil penelitian dan pembahasan maka peneliti menyimpulkan beberapa hal sebagai berikut.

1. Dari hasil uji regresi sederhana bahwa variabel harga jual memiliki nilai negatif 2,734 yang diartikan bahwa apabila terjadi penurunan harga sebesar $1 \%$ maka akan terjadi kenaikan nilai penjualan sebesar $2,734 \%$.

2. Dari hasil uji koefisien determinasi bahwa $R$ square sebesar 0,908 hal ini menunjukkan bahwa $90,8 \%$ varibel independen (harga jual) yang dapat menjelaskan variabel dependen (nilai penjualan). Sedangkan sisanya sebesar 9,2\% dipengaruhi atau dijelaskan oleh variabel lain yang tidak dimasukkan dalam penelitian ini.

3. Hasil uji t diperoleh variabel harga 9,951 dengan taraf signifikansi 0,000. Kemudian $\mathrm{t}_{\text {hitung }}$ dibandingkan dengan $\mathrm{t}_{\text {tabel }}$ pada $\mathrm{df}=$ $12-2=10$ dan tingkat signifikan 0,05 diperoleh nilai $t_{\text {tabel }} 2,228$. Nilai $t_{\text {hitung }}$ Variabel X lebih besar dari $t_{\text {tabel }}(9,951>$ 2,228). Adapun tingkat signifikan $0,000<$ 0,05. Pada Coefficiens Table diatas, nilai $t_{\text {hitung }}$ berslope negatif. Pada uji t, simbol negatif hanyalah menyatakan slope $\beta_{1}$. Jika nilai koefisien $\beta_{1}$ berslope negatif, maka nilai $\mathrm{t}$ hitung pun akan bernilai negatif. Sehingga angka yang digunakan dalam uji $\mathrm{t}$ hanyalah angka $\mathrm{t}$ hitung, tanpa menyertakan slope atas nilai $t$ hitung tersebut. Dari hasil pembahasan diatas, maka dapat dnyatakan bahwa Ho ditolak dan Ha diterima. Sehingga menunjukkan bahwa ada pengaruh signifikan terhadap nilai penjualan.

4. Mengacu kepada pertanyaan pada rumusan masalah yaitu Bagaimana pengaruh harga jual kaca patri jenis silver terhadap nilai penjualan pada CV. Karunia Kaca Palembang? Maka dari hasil pembahasan diatas dapat diketahui bahwa pengaruh antara harga dan volume penjualan produk kaca patri jenis silver pada CV. Karunia Kaca Palembang memiliki pengaruh yang berslope negatif sebesar 2,734. Hal ini mengartikan bahwa apabila terjadi penurunan harga sebesar $1 \%$ maka akan terjadi kenaikan nilai penjualan sebesar $2,734 \%$.

\section{Saran}

Berdasarkan kesimpulan diatas maka dapat diberikan saran sebagai berikut:

1. Diharapkan perusahaan memberikan harga jual yang sesuai dengan bahan baku kaca patri, dan menentukkan harga jual dengan melihat pangsa pasar dan melihat para pesaing dalam memberikan harga untuk konsumen dan pelanggan. Perusahaan diharapkan memberikan harga jual yang berbeda dengan pelanggan untuk mendapatkan pelanggan tetap. 
2. Diharapkan CV. Karunia Kaca Palembang dapat meningkatkan nilai penjualan, dengan menargetkan nilai penjualan pada setiap bulannya.

3. Meskipun hasil penelitian menunjukkan adanya pengaruh antara harga jual terhadap nilai penjualan tetapi $\mathrm{CV}$. Karunia Kaca Palembang harus memperhatikan variabel lain seperti produk, tempat, dan promosi.

\section{Daftar Pustaka}

[1] Patra, Eko. 2015 "Pengaruh Strategi Promosi Dan Harga Terhadap Volume Penjualan Alat Kesehatan (Hospital Bed) pada PT. Sarandi Karya Nugraha”. Jurnal JIMFE (Jurnal Ilmiah Manajemen Fakultas Ekonomi) Volume 1 No. 2. Universitas Pakuan Bogor.
[2] Abdurrahman. 2015. "Manajemen Strategi Pemasaran”. Edisi Pertama. Bandung. Pustaka Setia.

[3] Swastha, Basu 2014. "Manejemen Pemasaran”. Edisi Ketiga. Yogyakarta. Yogyakarta. BFFE.

[4] Sunyoto. 2015. "Strategi Pemasaran". Edisi Pertama. Yogyakarta.CAPS.

[5] Ginting. 2011. "Manajemen Pemasaran". Edisi Pertama. Yrma Widya. Bandung.

[6] Sugiyono. 2015"Metode Penelitian Manajemen" Edisi Keempat. Alfabeta. Bandung.

[7] Sugiyono. 2014. "Metode Penelitian Bisnis" Edisi Kedelapan belas. Alfabeta. Bandung. 